\title{
THE IMPLICATIONS OF THE UNITED KINGDOM'S EXIT FROM THE EUROPEAN UNION ON THE COMMON AGRICULTURAL POLICY
}

\author{
Aldona Zawojska, PhD, Associate Professor'; \\ Tomasz Siudek, PhD, Associate Professor ${ }^{2}$ \\ Faculty of Economic Sciences, Warsaw University of Life Sciences - SGGW
}

\begin{abstract}
The two-year Brexit process, formally initiated on March 2017, is coming to an end, intensifying public discussions and concerns about the future of the EU, including the community budget and policies. This paper articulates the likely implications of the United Kingdom's withdrawal from the EU on the Common Agricultural Policy using a political economy approach. It focuses on the budgetary and agricultural trade consequences of the Brexit for the EU remaining member states. The European Commission's proposed reduction by 5\% of the CAP budget for 2021-2027 is one of the first Brexit consequences that potentially can result in a decline in EU farm incomes. The leaving the single market and customs union by the UK, traditionally taking a liberal market position, will probably affect not only the CAP, but also agricultural policies amongst WTO and G20 member countries. With lack of some kind of free trade agreement between the UK and the EU, agri-food net exports from the EU27 to the UK will decrease.
\end{abstract}

Keywords: Brexit, European Union, Common Agricultural Policy

JEL codes: Q18, F5, F02, F36

\section{INTRODUCTION}

One of the major challenges facing the European Union (EU) in the coming years will be the handling the consequences of the United Kingdom's withdrawal from the EU - generally referred as to the 'Brexit' (British exit). Although the UK - the EU's third largest state according to population size, has been so far the greatest beneficiary of EU member states' differentiation (e.g. opt-outs from the Economic and Monetary Union and the Schengen system, permanent rebate on the EU budget), it decided to leave the EU. It was the first time in the EU history when a member state took steps, which finally will result in its withdrawing from the membership.

The procedural articulation of a member state's intent to leave the EU is provided in Article 50 of the Treaty of the European Union, according to which 'Any Member State may decide to withdraw from the Union in accordance with its own constitutional requirements' and 'A Member State which decides to withdraw shall notify the European Council of its intention' (Consolidated version of the Treaty, 2012). On the 23 June 2016, the people of the UK voted on the historic referendum (with modest majority of $51.9 \%$ ) in favour of leaving the EU. On the 29 March

${ }^{1}$ Corresponding author: Nowoursynowska 166, 02-787 Warsaw, Poland, aldona_zawojska@sggw.pl, +4822 5934036

${ }^{2}$ Corresponding author: Nowoursynowska 166,02-787 Warsaw, Poland, tomasz_siudek@sggw.pl, +4822 5934226 
2017, the UK's Prime Minister, Theresa May, notified the European Council of the intention to terminate its EU membership (Miller, 2016).

Article 50 allows for a two-year period of negotiations over terms of the exit and the future Britain's relationship with the EU regarding, i.a. the rights of EU citizens living in the UK, immigration, trade regimes, and the UK financial commitments to the EU. There are now (June 2018) exactly ten months to go before the UK officially becomes the first-ever former EU member state on the 29 March 2019. The UK and the EU have provisionally agreed on a large part of joint withdrawal deal, including a 21-month implementation or transitional phase which is due to last from Brexit day to the 31 December 2020. The UK will retain the benefits of the single market and customs union for this period but legal certainty will only be achieved once the final agreement is signed and ratified - likely in 2019 (Boffey, Asthana and O'Carroll 2018). It is widely reported, however, that the UK would pursue a 'hard' or 'clean' break from the EU, i.e. complete separation and a return to an arrangement that existed before its 1973 entry into the then European Economic Community. It would mean the UK outside of the single market and the EU customs union after 2020 (HM Government, 2017; Hamilton, 2018; Hunt, 2018; Piper and MacAskill, 2018).

As the level of interdependence between the UK and the EU is high, and the Great Britain's role in shaping and supporting the EU was seen as key, its departure will prompt significant changes and economic consequences for the remaining EU-27 member states.

The Brexit creates both individual and aggregate uncertainties on many fronts (political, policy, economic, financial, social, environmental, legal etc.) throughout the UK, the EU and even global economy. Individual uncertainty arises when there is doubt about the identities of likely winners and losers of change. Aggregate uncertainty occurs when there is uncertainty about the economy - or its sector-wide effects of given change - whether the overall effects will be positive or negative (Roland, 2002). Given these uncertainties, it becomes pertinent to consider what would be the likely post-Brexit effects on the Common Agricultural Policy (CAP). The purpose of the paper is to provide an overview of potential consequences that the Brexit may have on the CAP.

\section{THEORETICAL BACKGROUND}

This article takes a political economy perspective which integrates the analysis of political process (politics or rules of game) and economics (a game played within rules) (Buchanan, 1964). The basic proposition taken from Buchanan (1964) is that economics is about (1) exchange and (2) choices (over the rules and made under the rules chosen) and processes of adjustments. We follow normative political economy strand which investigates what economic policy should be enacted to produce ideal/desired effects or what policy would be enacted under some set of circumstances that may or will not obtain.

The UK's relationship with the EU has historically been determined by a complex interplay between political and economic interests framed in terms of costs and benefits of the EU membership (Jensen and Snaith, 2016; Menon and Salter, 2016). The bulk of the EU's spending in the UK is for agriculture - the European Agricultural Guarantee Fund is the largest fund (Keep, 2018). But British farmers are benefiting not only from the CAP subsidies but also from single agro-food market access.

As it concerns the EU agricultural sector, it enjoys political assets that can be translated into an influence on the CAP. Since the CAP came into existence in 1962, the governments of member states that benefit most from this policy have been its strong defenders - including France taking generally protectionist attitude towards the CAP and being the most notable permanent member of its 'anti-reform' club, and Germany (Nugent, 2017). The UK, in turn, long have been the EU most euro-sceptic member state that has continually pressed for European integration proceeding on a minimalist basis (a liberal internal market and most of other policy areas left to inter-governmental cooperation). Successive UK governments have been critical of the EU's blanket approach to supporting farmers through decoupled payments (CAP's Pillar 1), the policy that according to many observers (e.g.Swinbank, 2017b) is difficult to justify in social welfare terms, and results in the inflated 
land prices. The UK government traditionally takes a strong stance for a smaller CAP budget.

The agriculture is also sphere where there is significant interest group representation at national and supra-national levels (Zawojska, 2011). Farm unions and agri-cooperatives from across Europe are represented by the powerful lobby organization, CopaCogeca, the statutes of which require full member organizations to be from the EU countries. After the Brexit (29 March 2019), the National Farmers' Union of England and Wales (NFU) as well as the National Farmers' Union of Scotland, which played a vital part in work on the CAP, would no longer be Copa-Cogeca members. In the latest news, the NFU stated that it wants to remain in the membership group - at least during the transition period (Tasker, 2018).

The CAP is financed jointly by the member states out of the EU budget, and has a strong position within it since accounts for almost two-fifths of its total spending (EUR 59 billion in 2017). According to Begg (2018), the EU budget is a balancing act between three competing sets of demands: (1) the net contributors who want to keep EU expenditure as low as possible, especially against the backdrop of losing the national contributions resulting from the Brexit; (2) the powerful interest groups used to benefiting from EU funding, from the agricultural lobby to the rural regions receiving economic developments support; (3) new priorities, such as dealing with economic migration and refugee crisis, securing the EU external borders, countering terrorist threats and promoting the digital transformation.

As for the CAP effect on the relationship between the EU and non-EU states, this policy has fuelled many trade disputes between the EU and other agricultural exporters.

\section{MATERIALS AND METHODS}

The paper is descriptive in approach. It discusses the Brexit likely effects on the CAP. The analyses stem from a political economy perspective and are based on secondary sources such as more recent scientific papers, the EU and the UK official documents, disclosure bulletins, statistical databases, and news articles.
The study aims to address three main research questions: (1) How could Brexit impact the EU budget and the CAP financing?; (2) How could Brexit impact agricultural trade?; and (3) How could Brexit impact future CAP development?

\section{RESULTS}

The Brexit means the departure of the UK from the $\mathrm{CAP}$ - its subsidy and regulatory regimes. The nature and scale of any impact of Great Britain leaving both on the CAP and the EU agriculture will depend on the details of the agreement finally reached with the EU. In this section, the potential Brexit implications on different aspects of the CAP will be articulated.

\section{Impacts of Brexit on the CAP budget and farm incomes}

In 2016, the UK was the third largest net contributor, after Germany and France, to the Community budget (even allowing for a rebate on its contribution) with operating budgetary balance of EUR -5.6 billion (in 2015: EUR -11.7 billion). The total British contribution, and therefore potential loss for the EU budget revenue, amounted to EUR 12.8 billion in 2016 (in 2015: EUR 18.2 billion). This equals to $8.75 \%$ (2016) and $12.46 \%$ (2015) of the EU total budgetary revenue (European Commission, 2018a). In 2017 the UK made an estimated gross contribution (after the rebate) of GBP 13 billion while received GBP 4.1 billion of public sector receipts from the EU. So, the UK's net public sector contribution to the EU was an estimated GBP 8.9 billion. Considering additional EU funding allocated directly by the European Commission to UK organisations, an average annual net contribution was of GBP 8.5 billion between 2011 and 2015 (Keep, 2018).

The European Commission's budget proposals for the period 2021-2027, published on 2 May 2018 (European Commission, 2018b) indicate the negative financial effects of the UK departure both on the CAP budget and farm incomes. Having taken into account the UK withdrawal, the proposal includes reductions of roughly $5 \%$ both in the CAP and in the Cohesion Policy allocations since they have the largest financial envelopes and shares of the common budget (CAP: 
EUR 365 billion for 2021-2027; ca 30\% of budget commitments). The agricultural budget, if accepted by the member states and the European Parliament, would assume the full CAP-Brexit bill (EUR 18.9 billion). Additionally, it would loss EUR 24.2 billion due to its redeployment in order to fund other EU policies.

According to Farm Europe (2018) estimates, the actual net cost of Brexit for the CAP is EUR 2.7 billion per year in constant prices $(40 \%$ of the UK annual average net contributions to the EU budget in 2010-2016 which accounted for EUR 6.6 billion). If the entire decrease was affected to the Pillar 1, direct payments would be reduced by roughly $6.5 \%$. Majority of member states would face a decline in farm income, ranging from $2 \%$ to $4.5 \%$. The Brexit would lead to a fall in agricultural income of $3.6 \%$ on average in the Community.

\section{Impacts of Brexit on agricultural trade}

For the UK, an exit from the EU presents a trade-off between lacked or reduced access to the single market in exchange for greater freedom from the legal, regulatory and fiscal obligations related to the membership (Boulanger and Philippidis, 2015).

The UK Prime Minister has stated that the UK is leaving the single market and the customs union (what means the UK and EU will enjoy less access to each other's markets) so that the UK can strike its own trade deals around the world (Asthana et al., 2018). The UK government is keen to draw up a bespoke trade deal ('customs partnership') with the EU, allowing for the free flow of goods and services.

Nevertheless, under the political pressure and uncertainty surrounding the negotiations, it is worth considering the UK preferential access to the EU market. On the 8 May 2018, the House of Lords of the British parliament has backed calls for the UK to effectively remain in the EU's single market after Brexit. An amendment to the EU withdrawal bill obliging the UK to stay in the less stringent version of the single market - European Economic Area (EEA) after Brexit was backed by 245 votes to 218 , despite neither the government nor the Labour leadership backed it (BBC, 2018). Moreover, a hundred organisations from across the UK's food supply chain call for any Brexit deal that 'maintains continuity in existing trade arrangements as far as possible' (McDonnell, 2018).

Without the UK membership in the single market and any new trade agreement between the two sides, relative trade barriers will change by making UK's trade with the EU countries more expensive compared to outside EU trade. It could result in British trade creation with the non-EU countries and trade diversion away from the EU (Brakman et al., 2018).

The EU is the world's largest agricultural trader and has a positive trade balance with the rest of the world. The UK economy relies significantly on the EU for agri-food trade and vice versa. According to British Department for Environment, Food \& Rural Affairs (2017), the EU states are the leading foreign supplier of food consumed in the UK ( $30 \%$ in 2016). In 2016, the UK exports of food, feed and drink stood at GBP 20 billion whereas the UK imported a total of GBP 42.6 billion of these goods ${ }^{3}$. It is important to note that out of total British exports of these items, $60 \%$ were sold to EU countries while $70 \%$ of the UK imports came from the EU, mainly from the Netherlands (GBP 5.1 billion), the Irish Republic, France and Germany (GBP 4 billion each).

Considering that the UK - a net importer of agrifood products - imports twice as many these goods from the other EU countries than it exports, the negative impact of hard Brexit for the agri-food sector in the remaining member states would be a loss in their sales to the UK.

Another consequence arises from the ambition of the UK government 'to be a proud champion of global free trade and a strong supporter of the rules-based global trading system' (HM Government, 2017). As the UK departs from the EU, it will again take up its independent seat at the World Trade Organization (WTO) and thus will have potential influence on policy reform amongst the WTO (and G20) members

${ }^{3}$ The UK imports of agricultural products reached GBP 8.56 billion in 2017. 
after 2020. According to Mitchell (2017), following Brexit, the UK has a chance to demonstrate global leadership in the development of market-based model of agriculture that is better integrated and aligned with environmental and climate aspirations and commitments.

The results of quantitative assessment (Boulanger and Philippidis, 2015) of both budgetary and macroeconomic impacts on EU member states resulting from the post-Brexit establishment of the UK-EU Free Trade Agreement, narrowed to cover the agrifood trade and (extrapolated) CAP budgetary implications, reveal that this element of the UK's divorce would be beneficial to this country (net gains from CAP budget withdrawal exceed even the upper bound losses arising from trade facilitation costs on agrifood single market access).

\section{Impact of Brexit on future CAP development}

The impact of the UK's decision to leave the EU on the future CAP is generally unclear. We can suppose that with the UK (a strong advocate for the CAP reforms and greater market orientation of agriculture) exit from the EU, the balance of power within the EU-27 would shift towards member states sceptical of the CAP radical change.

Also according to Matthews (2016), the absence of the UK in future discussion of CAP would boost those voices among European parliamentarians and member states who wish to roll back some of the recent reforms and to focus more upon supporting farm incomes through strengthened public safety-nets and greater public intervention on agricultural markets. As concerns excessively high import tariffs on CAP agricultural commodities and associated food products, it seems questionable that the challenges posed by the UK departure would prompt the EU to unilaterally reduce them (Swinbank, 2017a).

From a more general political perspective, key challenges are relations between France and Germany in post-Brexit EU. Krotz and Schild (2018) suggest three basic future scenarios for the EU: (1) German hegemony; (2) the decline of the European project; and (3) the most likely and plausible - a rejuvenated Franco-German tandem at the EU's centre, called by them as a 'back to the future'.

\section{CONCLUSIONS}

The study leads to the following conclusions:

1. The consequences of the UK's departure from the EU in March 2019 will depend both on the final version of the EU-UK withdrawal agreement and national policies adopted by the UK government after the Brexit.

2. The Brexit will probably have not significant effect on future CAP development due to the exclusion from the EU policy-making process of one of the most reform-minded and liberal member states. The British moderating pressure has hitherto been a key factor in the developing a less protective EU agriculture and more open agricultural trade policy.

3. The UK status as the G20 member and developed economy, and fact that agriculture still remains a highly politicized area at the international level, together mean that British future agricultural and trade policy would have global relevance. The post-Brexit UK would exert an influence on policy reform in WTO and G20 member countries by shifting their attitudes to the market-oriented model of agriculture.

4. The Brexit-related reduction of roughly $5 \%$ in the CAP budget proposed by the European Commission for the 2021-2027 EU Multiannual Financial Framework may be expected to lead to a negative impact on farm incomes in several EU countries.

5. With hard Brexit option (no new trade deal between the EU and the UK) tariffs would be imposed on agri-food commodities that the UK sells to and buys from the EU. As the UK is now a net importer of these commodities from the EU countries, the agri-food sectors in the remaining member states would suffer loss of British agricultural markets.

\section{REFERENCES}

1. Asthana, A., Boffey, D., Perkins, A. (2018). Theresa May says Brexit will reduce UK access to single market. The Guardian. Retrieved from: https://www.theguardian.com/politics/2018/mar/02/theresa-may-saysbrexit-will-reduce-uk-access-to-single-market [Accessed 07.05.2018]. 
2. BBC, (2018). Brexit: Peers Call for UK to remain in European Economic Area. Retrieved: https://www.bbc. com/news/uk-politics-44038476 [Accessed 09.05.2018].

3. Begg, I. (2018). What to Know about the EU's New Budget, Chatham House. Retrieved from: https://www. chathamhouse.org/expert/comment/what-know-abouteu-s-new-budget. [Accessed 14.05.2018].

4. Boffey, D., Asthana, A., O'Carroll, L. (2018). Theresa May under fire over Brexit transition deal. The Guardian. Retrieved from: https://www.theguardian.com/politics/2018/mar/19/uk-and-eu-agree-terms-for-brexittransition-deal [Accessed 13.05.2018].

5. Boulanger, P., Philippidis, G. (2015). The End of a Romance? A Note on the Quantitative Impacts of a 'Brexit' from the EU. Journal of Agricultural Economics, 66 (3), pp. 832-842.

6. Brakman, S., Garretsen, H., Kohl, T. (2018). Consequences of Brexit and Options for a 'Global Britain'. Papers in Regional Science, 97 (1), pp. 55-72.

7. Buchanan, J.M. (1964). What Should Economists Do? Southern Economic Journal, 30 (3), pp. 213-222.

8. Consolidated version of the Treaty on European Union. OJ C 326 (Vol. 55) of 26.10.2012.

9. Department for Environment, Food \& Rural Affairs (2017). Agriculture in the United Kingdom. London.

10. European Commission (2018a). Budget in Figures. Interactive: EU Expenditure and Revenue 2014 -2020. Retrieved from: http://ec.europa.eu/budget/figures/interactive/index_en.cfm [Accessed 14.05.2018].

11. European Commission (2018b). Communication from the Commission. A Modern Budget for a Union that Protects, Empowers and Defends. The Multiannual Financial Framework for 2021-2027. COM(2018) 321 final.

12. Farm Europe (2018). Brexit: which impact on the CAP budget and on farm incomes? Retrieved from: http://www. farm-europe.eu/news/brexit-which-impact-on-the-capbudget-and-on-farm-incomes/ [Accessed 29.05.2018].

13. Hamilton, P. (2018). Hard Brexit is the Most Likely Outcome - PwC Warns. The Irish Times. Retrieved from: https://www.irishtimes.com/business/economy/ hard-brexit-is-the-most-likely-outcome-pwc-warns1.3459888 [Accessed 12.05.2018].

14. HM Government (2017). Future Customs Arrangements. A Future Partnership Paper. Department for Exiting the European Union, London.

15. Hunt, D. (2018). Amber Rudd leaving is a tragedy for EU! Analyst believes hard Brexit is now more likely. Express. Retrieved: https://www.express.co.uk/news/uk/953305/ Brexit-news-UK-EU-Amber-Rudd-European-UnionTheresa-May-Sajid-Javid. [Accessed 12.05.2018].
16. Jensen, M.D., Snaith, H. (2016). When Politics Prevails: The Political Economy of a Brexit. Journal of European Public Policy, 23 (9), pp. 1302-1310.

17. Keep, M. (2018). The UK's Contribution to the EU Budget. Briefing Paper CBP 7886. House of Commons Library, London.

18. Krotz, U., Schild, J. (2018). Back to the Future? Franco-German Bilateralism in Europe's Post-Brexit Union. Journal of European Public Policy, 25 (8), pp. 1174$-1193$.

19. McDonnell, F. (2018). Brexit deal must maintain trade continuity, businesses in North say. The Irish Times of 28.05.2018

20. Matthews, A. (2016). The Potential Implications of a Brexit for Future EU Agri-food Policies. EuroChoices, 15 (2), pp. 17-23.

21. Menon, A., Salter, J-P. (2016). Britain's Influence in the EU. National Institute Economic Review, 236 (1), pp. 7-13.

22. Miller, V. (ed.) (2016). Brexit: Impact across Policy Areas. Briefing Paper 07213. House of Commons Library, London.

23. Mitchell, I. (2017). The Implications of Brexit for UK, EU and Global Agricultural Reform in the Next Decade. Briefing November 2017. Chatham House, London.

24. Nugent, N. (2017). The Government and Politics of the European Union. Palgrave, Basingstoke.

25. Piper, E., MacAskill, A. (2018). Hard Brexit faction in May's party demands clean break from EU. Reuters. Retrieved from: https://www.reuters.com/article/ukbritain-eu-lawmakers/hard-brexit-faction-in-mays-party-demands-clean-break-from-eu-idUSKCN1G50PX [Accessed 9.05.2018].

26. Roland, G. (2002). The Political Economy of Transition. Journal of Economic Perspectives, 16(1), pp. 29-50.

27. Swinbank, A. (2017a). Brexit. Trade Agreements and CAP Reform. EuroChoices, 16 (2), pp. 4-9

28. Swinbank, A. (2017b). World Trade Rules and the Policy Options for British Agriculture Post-Brexit. Briefing Paper 7. UK Trade Policy Observatory, Sussex.

29. Tasker, J. (2018). Vote set to decide if NFU stays in EU farm lobby post Brexit. Farmers Weekly of 31.05.2018. Retrieved from: https://www.fwi.co.uk/news/eu-referendum/vote-set-to-decide-if-nfu-stays-in-eu-farm-lobby-post-brexit [Accessed 19.05.2018].

30. Zawojska, A. (2011). Pogoń za rentą i lobbing we wspólnej polityce rolnej Unii Europejskiej [Rent-Seeking and Lobbying in the EU's Common Agricultural Policy. Roczniki Nauk Rolniczych, Seria G - Ekonomika Rolnictwa, 98 (3), pp. 63-72. 